\section{Characterisation of epithelial cell line from rat cornea}

\author{
J. Jóźwiak \\ A. Komar \\ J. Malejczyk \\ Department of Histology \\ and Embryology \\ Medical University of Warsaw \\ Conclusion RtCE-1 cells may constitute a \\ model for the evaluation of proliferation, \\ function and differentiation of corneal \\ epithelium in vitro.
}

Warsaw, Poland

P. Skopiński

Department of Electron

Microscopy

Medical University of Warsaw

Warsaw, Poland

\section{A. Wójcik}

Department of Radiobiology and Health Protection

Institute of Chemistry and

Nuclear Technology

Warsaw, Poland

Jarosław Jóźwiak

Medical University of Warsaw

Department of Histology

and Embryology

UI. Chalubinskiego 5

02004 Warsaw, Poland

Tel/fax: +48226295282

e-mail:

yaro@ib.amwaw.edu.pl

This work was supported by the Committee for Scientific Research grant no. 6P20703106

Received: 15 February 2000 Accepted in revised form: 28 July 2000

Key words Cell line, Cornea, Epithelium, Rat

Corneal stratified epithelium plays an important role in maintaining homeostasis of the eye and forms a barrier for microbial facilitated by its high self-renewing trauma. ${ }^{3}$ The mechanisms of regeneration of by some growth factors, ${ }^{6,7}$ and may also be exists a possibility that some of these factors mechanisms of growth and differentiation of corneal epithelium are of significance.

In vitro models for studies of corneal utilise mainly primary epithelial cell cultures

\begin{abstract}
Purpose Characterisation of RtCE-1 cells, newly established rat corneal epithelial cell line.

Methods Morphology of RtCE-1 cells was characterised by light and electron microscopy. Expression of cytokeratins was studied by polyacrylamide electrophoresis and Western blotting. Characterisation of RtCE-1 cells also included karyotype analysis and in vitro study of growth kinetics.

Results The line shows morphological similarities to normal corneal epithelium. The cells express cornea-specific cytokeratins. Karyotype analysis revealed that the cells are polyploid with modal number of

chromosomes at passage 30 equalling $72 \pm 14$. Growth of the line is partially dependent on EGF.
\end{abstract} invasion. ${ }^{1}$ Functions of corneal epithelium are capabilities. $^{2}$ Furthermore, corneal epithelium displays a high regenerating potential following corneal epithelium involve an increased rate of cell proliferation, migration and spreading. ${ }^{3-5}$ These phenomena were found to be stimulated regulated by inflammatory cytokines. ${ }^{8,9}$ There may be useful for treatment of corneal trauma, especially in cases of chemical burns and other extensive wounds. ${ }^{10}$ Therefore, studies on the stratified epithelium growth and regeneration obtained by enzymatic isolation from human or animal corneas. ${ }^{11}$ However, these cultures are
J. JOZZWIAK, P. SKOPIŃSKI, A. KOMAR, A. WOJCIK, J. MALEJCZYK not infrequently overgrown by contaminating corneal fibroblasts making specific analysis difficult. Furthermore, studies on cultured normal corneal epithelial cells may also be difficult due to their limited in vitro life span. ${ }^{12}$ To overcome these problems, SV40immortalised corneal epithelial cells have been used. ${ }^{12-14}$ However, viral immortalisation usually leads to alteration or even absence of the differentiated phenotype. ${ }^{15,16}$ To our knowledge, extended subculture efforts aiming at generation of spontaneous corneal epithelial cell lines resulted in only one permanent spontaneously transformed rabbit cell line (RCE1). ${ }^{17}$ These cells retain the ability to form stratified cultures and express terminal differentiation-associated cytokeratins; nevertheless, their propagation requires the presence of $3 \mathrm{~T} 3$ feeder cells.

\section{Materials and methods}

\section{Culture medium}

A modified version of the medium for culture of rabbit corneal cells was used. ${ }^{17}$ The standard culture medium consisted of DMEM (Gibco BRL Life Technologies, Paisley, UK) and Ham's F12 Medium (Gibco) 3:1 mixture, supplemented with $10 \%$ fetal calf serum (FCS; Gibco), $0.4 \mu \mathrm{g} /$ $\mathrm{ml}$ hydrocortisone (Sigma, St Louis, MO), $10^{-10}$ $\mathrm{M}$ cholera toxin (Sigma), $5 \mu \mathrm{g} / \mathrm{ml}$ transferrin (Sigma), $5 \mu \mathrm{g} / \mathrm{ml}$ insulin (Sigma), $2 \times 10^{-11} \mathrm{M}$ triiodothyronine (Sigma), $2 \mathrm{mM}$ glutamine (Sigma), 1\% antibiotic-antimycotic solution (Gibco) and $5 \mathrm{ng} / \mathrm{ml}$ epidermal growth factor (EGF; Sigma).

\section{Isolation and culture of corneal epithelial cells}

All animal studies conformed to the principles determined by the Association of Research in Vision and Ophthalmology Resolution on the Use of Animals in Research.

Corneas were excised from 5 inbred male Wistar Albino Glaxo (WAG) rats killed by an overdose of diethyl ether. Each cornea was separated from the globe by a circular incision including the limbus. The corneas were then rinsed in phosphate-buffered saline (PBS; Gibco) and transferred into dispase II (Boehringer, Mannheim, Germany) in PBS 
without $\mathrm{Ca}^{2+}$ and $\mathrm{Mg}^{2+}$ and incubated at $37{ }^{\circ} \mathrm{C}$ for $1 \mathrm{~h}$. Following this the epithelial layer was separated mechanically under a dissecting microscope, cut into small pieces and transferred to $0.05 \%$ trypsin, $0.02 \%$ EDTA solution (Gibco) for $10 \mathrm{~min}$. The cells were dispersed by gentle pipetting, rinsed with the culture medium and seeded onto a $35 \mathrm{~mm}$ plastic culture dish (Costar, Cambridge, MA). After 1 week the cells were trypsinised and transferred into $25 \mathrm{~cm}^{2}$ culture bottles (Costar). The medium was changed every 3-4 days. The cells were split when necessary using trypsin/EDTA solution.

The cells were routinely frozen at $-7{ }^{\circ} \mathrm{C}$ in a solution containing 15\% DMEM supplemented with $1.1 \mathrm{M}$ glucose, 10\% dimethyl sulphoxide (DMSO; Sigma, St Louis, MO) and $75 \% \mathrm{FCS}$ at the cooling rate of $1{ }^{\circ} \mathrm{C} / \mathrm{min}$ and stored in liquid nitrogen.

To produce stratified cultures, the cells were seeded on porous bottom dishes (Transwell, Costar) at a density of 500000 cells per $6.5 \mathrm{~mm}$ diameter well and cultured for 1 week in standard culture medium changed every 2 days.

\section{Evaluation of cell proliferation}

For estimation of population doubling time (PDT) the cells were seeded into $25 \mathrm{~cm}^{2}$ bottles at a density of $2 \times$ $10^{5} / \mathrm{cm}^{2}$ in the standard culture medium with or without EGF. The cells from duplicate bottles were trypsinised after 12, 24, 48 and $72 \mathrm{~h}$ and counted in a Burker's chamber. The average of four independent cell counts was used to estimate the cell number. PDT was calculated by the least squares method.

\section{Light and electron microscopy}

Monolayer cultures grown on $12 \mathrm{~cm}$ coverslips were fixed with cold methanol and stained routinely with haematoxylin and eosin. Stratified cultures grown on porous membranes were fixed in $3 \%$ glutaraldehyde in

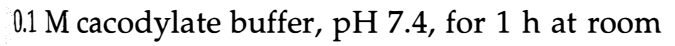
temperature. Then they were washed three times in cacodylate buffer, $\mathrm{pH} 7.4$, and fixed in $1 \% \mathrm{OsO}_{4}$ in $0.1 \mathrm{M}$ cacodylate buffer, $\mathrm{pH} \mathrm{7.4}$, at $4{ }^{\circ} \mathrm{C}$ for $1 \mathrm{~h}$. After fixation, material was dehydrated in an ethyl alcohol gradient followed by propylene oxide and embedded in lowviscosity epoxy resin. ${ }^{18}$ Semithin sections perpendicular to the culture surface were stained with methylene blue. Ultrathin sections were cut on an OmU 3 ultramicrotome (Reichert), stained with uranyl acetate ${ }^{19}$ and lead citrate, ${ }^{20}$ and inspected in a JEM $100 \mathrm{C}$ electron microscope.

\section{Immunofluorescence}

The cells grown on glass $12 \mathrm{~mm}$ coverslips were fixed in methanol at $-20{ }^{\circ} \mathrm{C}$ for $15 \mathrm{~min}$. They were exposed to AE1 (specific for most of the acidic keratins) or AE5 (specific for $64 \mathrm{kDa}$ keratin 3) monoclonal antibodies both from ICN Pharmaceuticals, Irvine, CA), followed by the secondary fluorescein isothiocyanate (FITC)- labelled goat antimouse IgG (Sigma, St Louis, MO). Stained cells were mounted in Mowiol - DAB CO ${ }^{21}$ (both obtained from Sigma, St Louis, MO) and inspected under a Microphot-FX fluorescence microscope (Nikon, Japan).

\section{Cytokeratin PAGE and Western blotting}

Cultured cells $\left(1 \times 10^{7}\right)$ were rinsed twice with cold PBS, scraped from the culture dishes with a rubber policeman, and homogenised in an extraction solution in order to remove water-soluble proteins. Extraction solution contained $5 \mu \mathrm{g} / \mathrm{ml}$ pepstatine A (Sigma, St Louis, MO), 1 $\mathrm{mM}$ EDTA, $1 \mathrm{mM}$ EGTA and $1 \mathrm{mM}$ phenylmethylsulphonyl fluoride (Sigma) and $25 \mathrm{mM}$ Tris- $\mathrm{HCl}$ ( $\mathrm{pH} 7.4$ ). Keratin-like proteins were obtained by centrifugation at $10000 \mathrm{~g}$ for $30 \mathrm{~min}$. The extraction procedure was repeated and the solution left overnight. After centrifugation the pellets were solubilised in $100 \mu \mathrm{l}$ of $1 \%$ SDS containing $25 \mathrm{mM}$ Tris- $\mathrm{HCl}$ and $10 \mathrm{mM}$ dithiothreitol (DTT) by heating at $95^{\circ} \mathrm{C}$ for $10 \mathrm{~min}$. Solubilised material was cleared by centrifugation for 5 $\mathrm{min}$ at $10000 \mathrm{~g}$. Proteins were separated by SDSpolyacrylamide gel electrophoresis (SDS-PAGE; $12 \%$ acrylamide), and transferred onto a nitrocellulose membrane by semi-dry blotting using Biorad's TransBlot SD apparatus (Biorad Laboratories, Hercules, CA). Cytokeratins were detected by AE1 or AE5 antibodies followed by an amplified alkaline phosphatase detection system (Biorad). Prestained low-molecular-weight standard (Biorad) was used for estimation of the relative molecular weight.

For visualisation of total PAGE-separated proteins the gel was fixed by soaking in 50\% methanol for a least $1 \mathrm{~h}$. Then, the proteins were stained with a solution containing $0.8 \%$ of silver nitrate, $0.08 \%$ of $\mathrm{NaOH}$ and $1.4 \%$ of $14.8 \mathrm{M}$ ammonium hydroxide and soaked in developing solution containing $0.025 \%$ of citric acid and $0.02 \%$ of formaldehyde. ${ }^{22}$

\section{Karyotyping}

Exponentially growing cells were incubated with Colcemid $(0.5 \mu \mathrm{g} / 10 \mathrm{ml}$ of medium $)$ at $37{ }^{\circ} \mathrm{C}$ for $2 \mathrm{~h}$. The cell were harvested by trypsinisation and treated with $0.075 \mathrm{M} \mathrm{KCl}$ at $37{ }^{\circ} \mathrm{C}$ for $15 \mathrm{~min}$. After fixation in methanol-acetic acid the cells were pipetted onto slides, air-dried and stained with $10 \%$ Giemsa solution.

Chromosome number was calculated in 50 metaphases. Chromosome pattern was compared with the normal rat karyotype presented by Levan and Levan. ${ }^{23}$

\section{Cell transplantation}

The suspension of $5 \times 10^{6}$ cells in $200 \mu$ l of PBS was injected subcutaneously at the ear base of 5 male WAG rats. Animals were inspected weekly and the tissues at the site of injection were taken for histological examination after 4 and 8 weeks. 


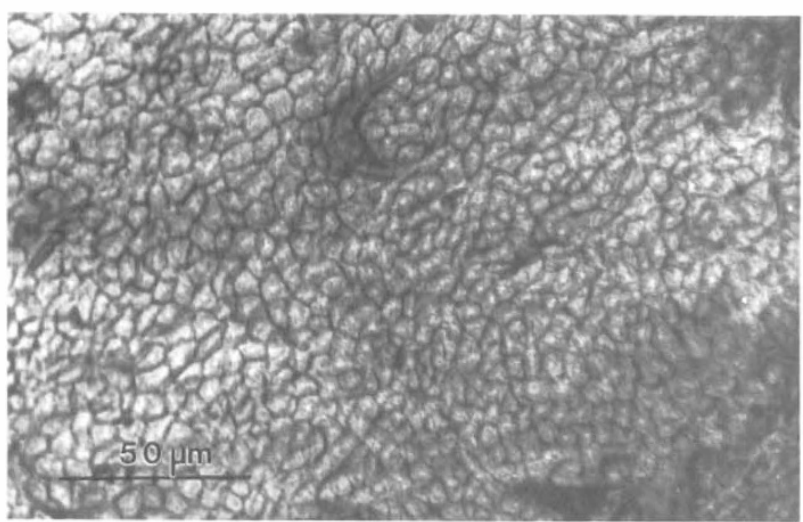

Fig. 1. Appearance of confluent monolayer culture of RtCE-1 cells under phase-contrast microscopy. Original magnification approx. $\times 800$.

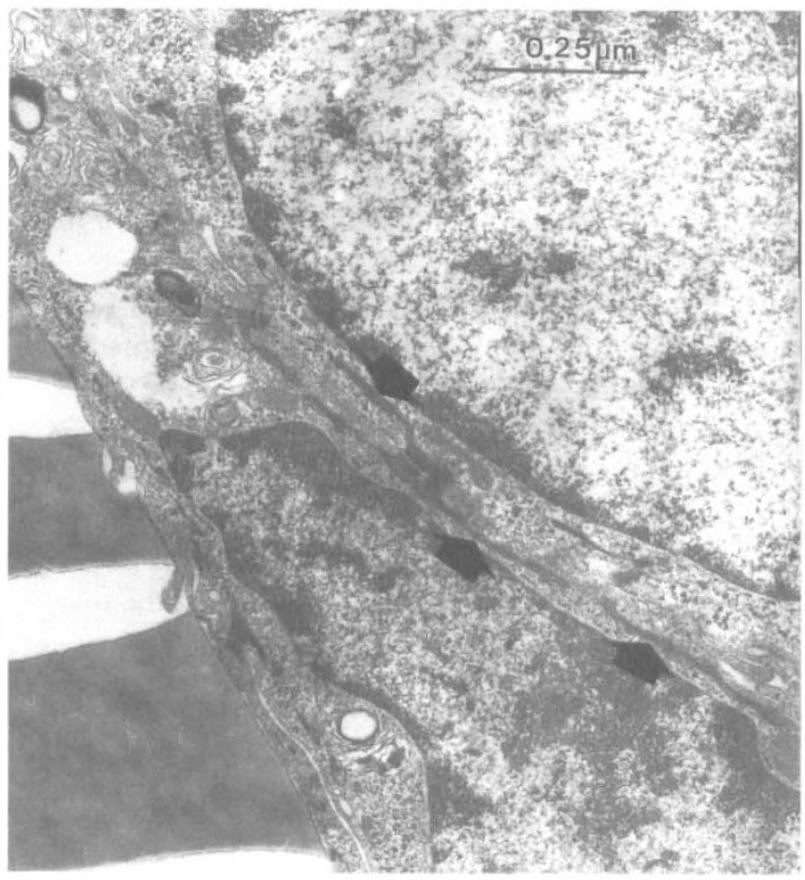

Fig. 3. Electron micrograph showing RtCE-1 cells grown in a porous bottom dish. The arrows indicate cytokeratin filaments. Original magnification approx. $\times 35000$.

\section{Results}

\section{Establishment of the corneal epithelial cell line}

Primary cultures of cells obtained from corneal epithelium contained epithelial-like cells which reached confluency in about 5 days. Following the first passage a number of epithelial cells displayed a differentiated phenotype and detached from the culture vessel. The cultures were gradually overgrown by fibroblast-like elongated cells which covered nearly the whole surface of the bottle and masked epithelial cells. One culture containing mostly fibroblastoid cells was left for 1 month with occasional change of medium. Then, a small, slowly growing colony composed of polygonal cells could be observed. After the following 2 weeks these cells covered approximately $70 \%$ of the surface. Two-step trypsinisation resulted in elimination of fibroblasts already after the fourth passage. Growth of the epithelial

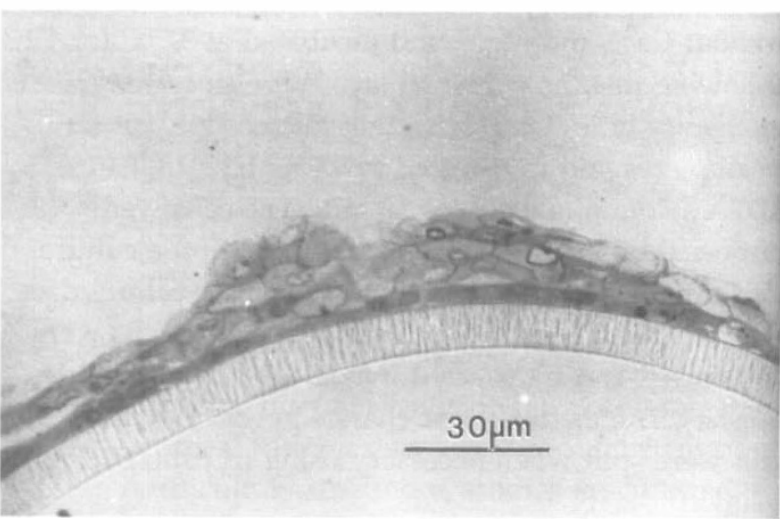

Fig. 2. Several layers of RtCE-1 cells grown in a porous bottom dish. The basal layer is continuous and more packed while cells in superficial layers are larger and paler. Light microscopy; original magnification approx. $\times 1000$.

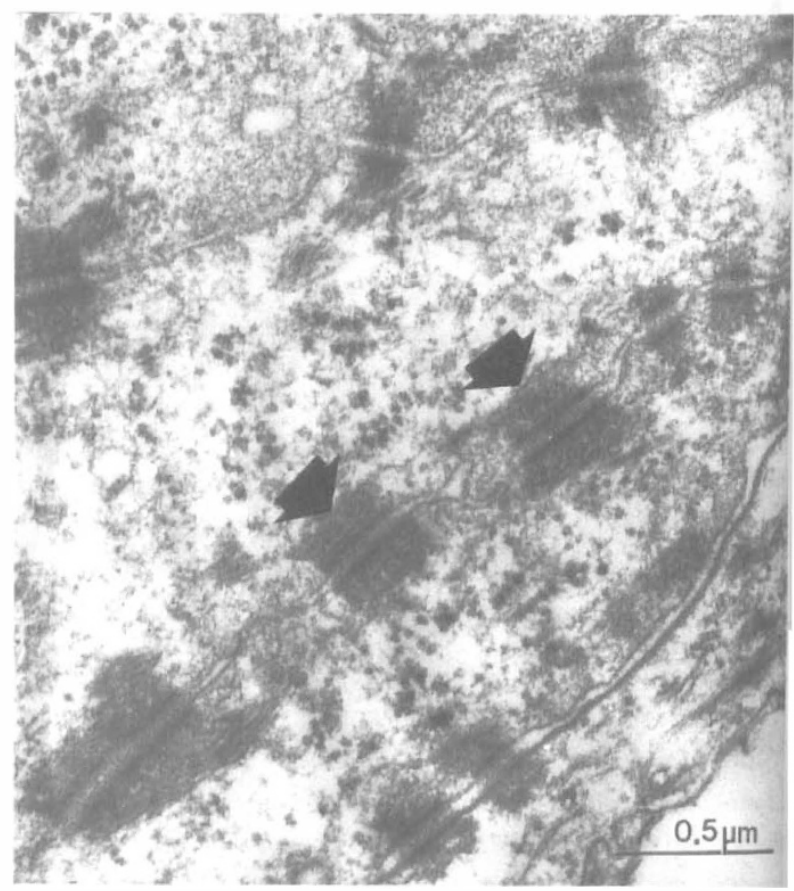

Fig. 4. Prominent numerous desmosomes (arrows) in adjacent RtCE-1 cells. Electron microscopy; original magnificantion approx. $\times 70000$.

cells was not affected by the removal of fibroblasts, and to date the cells have reached passage 63 . The developed cell line was named RtCE-1.

\section{Evaluation of the morphology of RtCE-1 cells}

RtCE-1 cells grown in monolayer culture displayed epithelial-like cuboid morphology (Fig. 1). When seeded at high density onto porous membranes the cells formed multilayer cultures with basal cells displaying basophilic cytoplasm and ovoid slightly flattened nuclei (Fig. 2). This basal layer was covered with a few (usually three or four) layers of cells with pale swollen cytoplasm and nuclei with chromatin concentrated close to the nuclear envelope.

Analysis of multilayer cultures by electron microscopy showed that the basal layer consisted of cells with high electron density and numerous bundles of filaments 


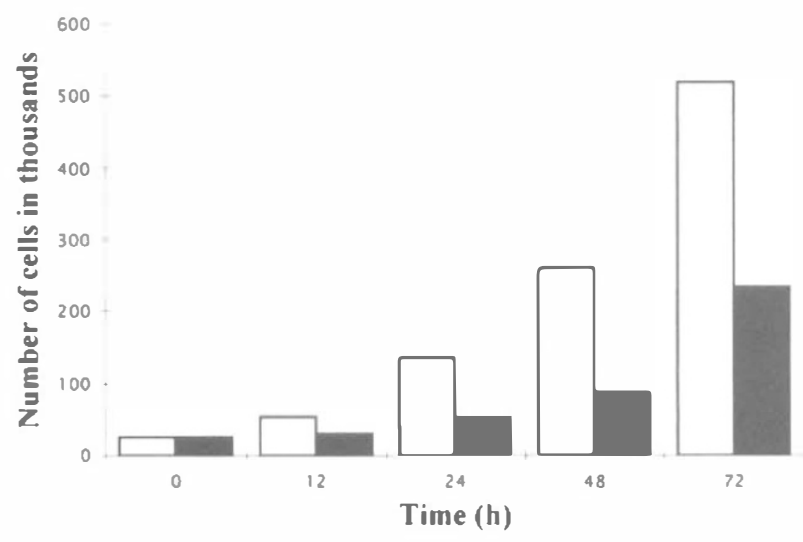

Fig. 5. Comparison of proliferation rate of RtCE-1 cells grown with (open bars) and without $5 \mathrm{ng} / \mathrm{ml}$ EGF (filled bars).

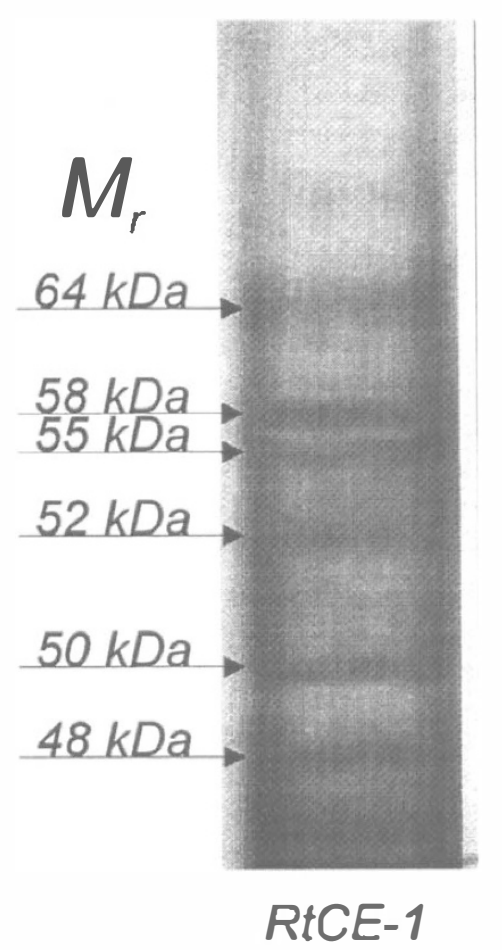

Fig. 7. Polyacrylamide gel after electrophoresis of RtCE-1 extract, followed by silver staining.

(Fig. 3). These filaments were associated with numerous desmosomes (Fig. 4). Intercellular spaces contained extensions of neighbouring cells, some of which penetrated into the pores of the culture membrane. Cells in superficial layers were larger and of lower electron density than the basal cells. Filaments were more dispersed but the presence of numerous desmosomes marking the limit of a cell was still evidence. Cytoplasm was vacuolated and some cells were degenerated.

\section{Evaluation of the proliferative potential of RtCE-1 cells}

The cells cultured in standard culture medium with epithelial growth factor (EGF) displayed a relatively high proliferative potential. Their PDT at passage 47 was 16.1 h. Removal of EGF resulted in a significant increase in PDT to $22.9 \mathrm{~h}$ (Fig. 5). During the observation period there were no significant differences in proliferation rate of RtCE-1 cells irrespective of earlier or later cell passage.

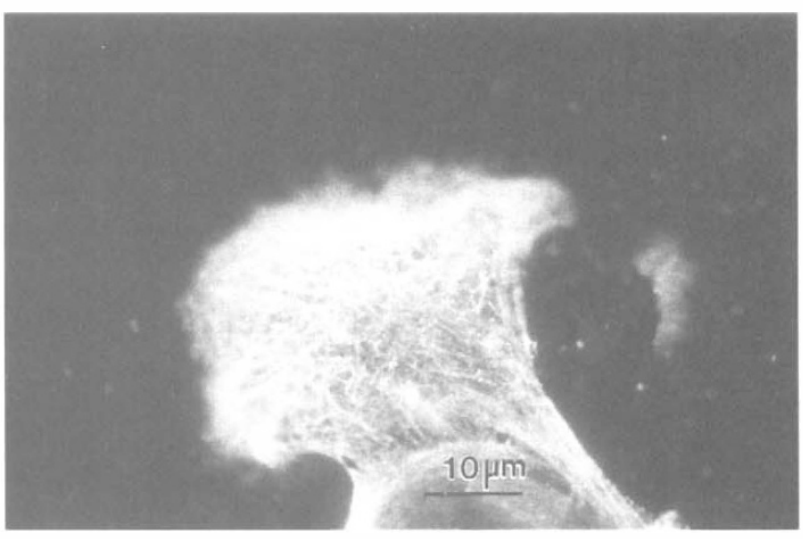

Fig. 6. Cytokeratin pattern displayed after immunohistochemical staining of RtCE-1 cells with AE1 antibody. Fluorescence microscopy; original magnification approx. $\times 800$.

\section{Expression of cytokeratins by RtCE-1 cells}

Fluorescence micoscopic analysis revealed that the cells grown in standard culture medium with EGF stained positively with AE1 antibody. The staining pattern showed a typical filamentous network, particularly dense at the cell periphery (Fig. 6). AE5 antibody specific for $64 \mathrm{kDa}(\mathrm{K} 3)$ keratin did not reveal significant staining of keratin filaments in the majority of cells. Occasionally cells with weak peripheral fluorescence were observed. ${ }^{24}$

SDS-PAGE electrophoresis of RtCE-1 water-insoluble cell extracts followed by silver staining detection of proteins showed major bands with molecular weights of $64 \mathrm{kDa}, 62 \mathrm{kDa}, 58 \mathrm{kDa}, 55 \mathrm{kDa}, 52 \mathrm{kDa}, 50 \mathrm{kDa}$ and 48 kDa (Fig. 7).

\section{Immunoblot detection of $\mathrm{K} 3$}

AE5 antibody did not show any bands.

\section{Analysis of the RtCE-1 karyotype}

A typical karyotype of RtCE cells at passage 30 is shown in Fig. 8. The modal number of chromosomes at passages 30 and 62 was $72 \pm 14$ and $74 \pm 11$, respectively. The arithmetic mean of the chromosome number was 71.62 $(\mathrm{SD} \pm 3.69)$ and $73.74(\mathrm{SD} \pm 3.42)$. The incidence of passage 30 cells with particular numbers of chromosomes is presented in Table 1. Comparison of normal and RtCE1 cell line karyotypes is given in Table 2 .

Table 1. Number of cells with a particular number of chromosomes

\begin{tabular}{cc}
\hline No. of chromosomes & Incidence (no. of cells) \\
\hline 58 & 1 \\
62 & 1 \\
66 & 1 \\
67 & 3 \\
68 & 1 \\
69 & 3 \\
70 & 7 \\
71 & 1 \\
72 & 13 \\
73 & 2 \\
74 & 8 \\
75 & 4 \\
76 & 4 \\
80 & 1 \\
\hline
\end{tabular}




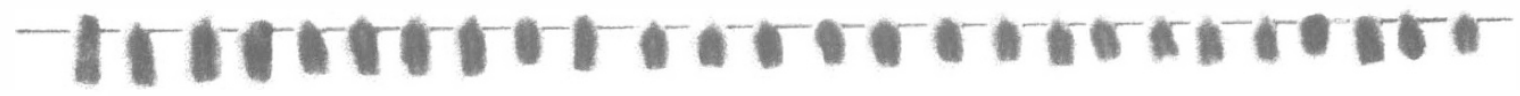

\author{
Group C. Chromosomes $11-13$ \\ $-1-4-8-3-1$
}

Group D. Chromosomes $14-20$

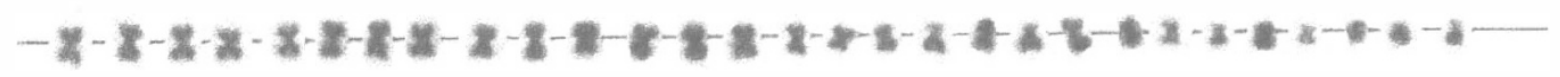

Sex chromosome

\section{Marker chromosomes}

Fig. 8 Representative karyotype of RtCE-1 cells. Chromosomes were divided into six groups according to Levan and Levan: ${ }^{23}$ group A, chromosomes 1-3; group B, chromosomes 4-10; group C, chromosomes 11-13; group D, chromosomes 14-20.

\section{Tranplantation}

There were no signs of tumour formation by RtCE-1 cells either 4 or 8 weeks after injection of $10 \times 10^{6}$ cells in 100 $\mu l$ of PBS into the left ear of 5 rats.

\section{Discussion}

The present paper describes a new RtCE-1 cell line derived from rat corneal stratified epithelium. The epithelial nature of these cells has been confirmed by both light and electron microscopic examinations. RtCE-1 cells display a typical cobblestone appearance and their cytoplasm contains numerous keratin-like filaments. Furthermore, they are able to stratify and form typical tight cell-cell junctions with numerous desmosomes. ${ }^{25}$

To confirm the origin of the RtCE-1 line the cells were also analysed for the expression of cornea-specific cytokeratins. Immunofluorescence analysis of RtCE-1 cells revealed a positive reaction with AE1 monoclonal antibody recognising most of the acidic keratins

Table 2. Comparison of normal rat karyotype and the karyotype of RtCE-1 cell line

\begin{tabular}{lcc}
\hline & $\begin{array}{c}\text { Normal } \\
\text { karyotype }\end{array}$ & $\begin{array}{c}\text { Karyotype of } \\
\text { RtCE-1 line }\end{array}$ \\
\hline Group A $^{b}$ & 6 & 7 \\
Group B $^{b}$ & 14 & 26 \\
Group C $^{b}$ & 6 & 8 \\
Group D & 14 & 29 \\
Sex chromosomes & 2 & $1^{c}$ \\
Marker chromosomes & - & 2 \\
\hline
\end{tabular}

${ }^{a}$ The most frequent karyotype

${ }^{b}$ Chromosome grouping according to Levan and Levan. ${ }^{23}$

${ }^{c}$ Chromosome $\mathrm{X}$ was probably included in group $\mathrm{B}$, since it is similar to chromsome 5 . including $50 \mathrm{kDa}$ class cytokeratins expressed by cultured cells originating from squamous epithelia. ${ }^{26-29}$ Furthermore, SDS-PAGE analsis of RtCE-1 cell waterinsoluble extracts showed a cytokeratin pattern similar to that of normal corneal stratified epithelium. This included a pair of $55 \mathrm{kDa}$ (K12) and $64 \mathrm{kDa}$ (K3) cytokeratins which are considered as cornea-specific, ${ }^{27,28}$ thus suggesting the corneal origin of RtCE-1 cells. Schermer et al. ${ }^{27}$ showed that basic $64 \mathrm{kDa}$ K3 keratin detected by AE5 monoclonal antibody is localised in all layers of corneal epithelium, but only in suprabasal layers of the limbal epithelium. However, we were unable to detect significant expression of this keratin in RtCE-1 cells by immunofluorescence or by Western blot analysis using AE5 monoclonal antibody (data not shown). It should be stressed, however, that while AE5 antibody has primary specificity towards $\mathrm{K} 3$ of human origin and cross-reacts with monkey and rabbit cytokeratins, ${ }^{28}$ it has been reported not to react with either fresh or cultured murine corneal epithelium. ${ }^{30}$ Furthermore, it has been found that expression of K3 keratin may be greatly decreased in exponentially growing cultures. ${ }^{27,31}$

Epithelial cell cultures, including cultures of corneal epithelium, require the presence of feeder-layer cells ${ }^{17}$ or growth factor supplementation. ${ }^{6,24,32}$ Indeed, RtCE-1 cells have been derived using medium containing factors delaying epithelial cell differentiation, i.e. EGF and cholera toxin. In medium supplemented with EGF RtCE1 cells display a relatively high proliferative potential. Corneal epithelium expresses EGF receptors ${ }^{33}$ and EGF supplementation of corneal epithelial cell cultures has been found to result in an increased proliferation and migration rate, ${ }^{6,7,9,24}$ Furthermore, EGF has been 
reported to accelerate corneal wound healing. ${ }^{10}$ Removal of EGF resulted in a significant decrease in RtCE-1 proliferation; however, the cells still retained the ability to grow. This may suggest that in later passages of RtCE1 cells EGF may not be absolutely necessary. RtCE- 1 cell requirements for other growth factors remain to be established.

Though it was possible to immortalise rabbit ${ }^{12}$ and human ${ }^{13}$ corneal keratinocytes, e.g. by virus infection, it is obvious that spontaneously obtained cell lines retain a phenotype closer to that expressed by primary cultures than do cells transfected with a virus. For this reason spontaneously obtained cell lines are more suitable for in vitro studies on function of the original tissue. ${ }^{34,35}$

Since normal corneal epithelial cells display a definitie in vitro life span and usually differentiate and die following several passages it appears that RtCE-1 cells underwent spontaneous immortalisation. Such immortalisation might be due to spontaneous epigenetic events affecting the function of some growth regulatory genes. ${ }^{38}$ Genetic events responsible for immortalisation of RtCE-1 cells remain unknown. However, autonomous growth of established immortal cell lines may be, at least partially, explained by polyploidisation which, however, is certainly not sufficient for malignant conversion. ${ }^{35}$ As other authors report, ${ }^{17,34}$ rodent spontaneous epithelial lines with diploid or nearly diploid chromosome number need to be cultured on feeder layers. Karyotype studies on RtCE-1 support these findings, showing that the modal number of chromosomes in RtCE- 1 cells is 72 . We did not find differences between the number of chromosomes at early (30) and late (62) passages. Therefore, it appears that the rate of polyploidy of RtCE1 cells is stable. In some RtCE- 1 cells abnormal chromosomes could be seen; however, a possible significance of this finding requires further investigation.

RtCE-1 cells did not display tumorigenic potential when transplanted into syngeneic animals. They also seem to retain features of normal corneal epithelium including the ability to stratify. They may be easily propagated without the need for a feeder layer and may thus constitute a good in vitro model for various studies concerning corneal epithelium function, proliferation and differentiation. RtCE-1 cells might also be useful as an alternative or complementary model for various in vivo pharmacological tests such as the Draize ocular irritation test, ${ }^{37}$ as well as for studies on in vitro construction of corneal equivalents. ${ }^{38,39}$

\section{References}

1. Mackenzie IC. The cellular architecture of the stratum and corneum. In: Marks R, Plewig G, editors. Stratum corneum. Berlin: Springer, 1983:146-52.

2. Tweng SCG. Regulation and clinical implications of corneal epithelial stem cells. Mol Biol Rep 1996;23:47-58.

3. Costarelis G, Cheng SZ, Dong G, Sun TT, Levker RM. Existence of slow-cyclic limbal epithelial basal cells that can be preferentially stimulated to proliferate: implications on epithelial stem cells. Cell 1989;57:201-9.
4. Chan KY, Patton DL, Cosgrove YT. Time-lapse videomicroscopic study of in vitro wound closure in rabbit corneal cells. Invest Ophthalmol Vis Sci 1989;30:2488-98.

5. Takeuchi S. The rearrangement of cytoskeletal systems in epithelial cells accompanying the transition from a stationery to motile state at the start of epithelial spreading. J Cell Sci 1987;88:109-19.

6. Savage CR Jr, Cohen S. Proliferation of corneal epithelium induced by epidermal growth factor. Exp Eye Res 1973;15:361-6.

7. Watanabe K, Nagakawa S, Nishida T. Stimulatory effects of fibronectin and EGF on migration of corneal epithelial cells. Invest Ophthalmol Vis Sci 1987;28:205-11.

8. Nishida T, Nakamura M, Mishima H, Otori T. Interleukin 6 promotes epithelial migration by a fibronectin-dependent mechanism. J Cell Physiol 1992;153:1-5.

9. Boisjoly HM, Laplante C, Bernatchez SF, Salesse C, Giasson M, Joly MC. Effects of EGF, IL-1 and their combination on in vitro corneal epithelial wound closure and cell chemotaxis. Exp Eye Res 1993;57:293-300.

10. Brazzell RK, Stern ME, Aquavell JV, Beuerman RW, Baird L. Human recombinant epidermal growth factor in experimental corneal wound healing. Invest Ophthalmol Vis Sci 1991;32:336-40.

11. Gipson IK, Grill SM. A technique for obtaining sheets of intact rabbit corneal epithelium. Invest Ophthalmol Vis Sci 1982;23:269-73.

12. Araki K, Ohashi Y, Sasabe T, Kinoshita S, Hayashi K, Yang $X Z$, et al. Immortalization of rabbit corneal epithelial cells by a recombinant SV-40 adenovirus vector. Invest Ophthalmol Vis Sci 1993;34:2665-71.

13. Kahn RC, Young E, Lee IH, Rhim JS. Human corneal epithelial primary cultures and cell lines with extended life span: in vitro model for ocular studies. Invest Ophthalmol Vis Sci 1993;34:3429-41.

14. Araki-Sasaki K, Ohashi Y, Sasabe T, Hayashi K, Watanabe H, Tano Y, Handa H. An SV40-immortalized human corneal epithelial cell line and its characterization. Invest Ophthalmol Vis Sci 1995;36:614-21.

15. Scholte BJ, Kansen M, Hoogeveen AT, Willemse R, Rhim JS, Van der Kamp AWM, Bijman J. Immortalization of nasal polyp epithelial cells from cystic fibrosis patients. Exp Cell Res 1989;182:559-71.

16. Agarwal C, Rorke EA, Irwin JC, Eckert RL. Immortalization by human papillomavirus type 16 alters retinoid regulation of human ectocervical epithelial cell differentiation. Cancer Res 1999;51:3982-9.

17. Castro-Munozledo F. Development of a spontaneous permanent cell line of rabbit corneal epithelial cells that undergoes sequential stages of differentiation in cell culture. J Cell Sci 1994;107:2343-51.

18. Spurr AR. A low-viscosity epoxy resin embedding medium for electron microscopy. J Ultrastruct Res 1969;26:31-43.

19. Farquhar MG, Palade GE. Cell junctions in amphibian skin. J Cell Biol 1965;26:263-91.

20. Reynolds ES. The use of lead citrate at high $\mathrm{pH}$ as an electron-opaque stain in electron microscopy. J Cell Biol 1963;17:208-12.

21. Langanger G, De Mey J, Adam H. 1,4-Diazobizyclo-[2.2.2]Oktan (DABCO) verzögert das Ausbleichen von Immunfluoreszenzpräparaten. Mikroskopie (Wien) 1983;40:237-41.

22. Hames BD, Rickwood D. Gel electrophoresis of proteins: a practical approach, 2nd ed. Oxford: Oxford University Press, 1994:60-3.

23. Levan G, Levan A. Specific chromosome changes in malignancy: studies in rat sarcomas induced by two polycyclic hydrocarbons. Hereditas 1975;79:161-98. 
24. Kruse FE, Tseng SCG. Growth factors modulate clonal growth and differentiation of cultured rabbit limbal and corneal epithelium. Invest Ophthalmol Vis Sci 1993;34:196376.

25. Kenyon KR. Morphology and pathologic responses of the cornea to disease. In: Smolin G, Thoft RA, editors. The cornea. Boston: Little, Brown, 1983;43-75.

26. Rodriguez M, Ben-Zvi A, Krachmer J, Schermer A, Sun T-T. Suprabasal expression of a 64-kilodalton keratin (no. 3) in developing human corneal epithelium. Differentiation 1987;34:60-7.

27. Schermer A, Galvin S, Sun T-T. Differentiation-related expression of a major $64 \mathrm{kDa}$ keratin in vivo and in culture suggests limbal location of corneal stem cells. J Cell Biol 1986;103:49-62.

28. Tseng SCG, Jarvinen MJ, Nelson WG, Woodcock HJ-W, Mitchell J, Sun T-T. Correlation of specific keratins with different types of epithelial differentiation: monoclonal antibodies studies. Cell 1982;30:361-72.

29. Nelson WG, Sun T-T. The 50- and 58-kilodalton keratin classes as molecular markers for stratified squamous epithelia: cell culture studies. J Cell Biol 1983;97:244-51.

30. Hazlett L, Masinisc S, Mezger B, Barrett R, Kurpakus M, Garrett M. Ultrastructural, immunohistological and biochemical characterisation of cultured mouse cornal epithelial cells. Ophthalmic Res 1996;28:50-6.

31. Doran TI, Vidrich A, Sun T-T. Intrinsic and extrinsic regulation of the differentiation of skin, corneal and esophageal epithelial cells. Cell 1980;22:17-25.
32. Jumblatt MM, Neufeld AH. $\beta$-Adrenergic and serotonergic responsiveness of rabbit corneal cells in culture. Invest Ophthalmol Vis Sci 1983;24:1139-43.

33. Frati L, Daniele S, Delogu A, Covelli I. Selective binding of the epidermal growth factor and its specific effects on the epithelial cells of the cornea. Exp Res Res 1972;14:135-41.

34. Negrel R, Rampel P, Nan JL, Cavenel C, Ailhaud G. Establishment and characterisation of an epithelial intestinal cell line from rat fetus. Exp Cell Res 1983;143:427-37.

35. Boukamp P, Petrussevska RT, Breitkreutz D, Hornung J, Markham A, Fusenig NE. Normal keratinization in a spontaneously immortalized aneuploid human keratinocyte cell line. J Cell Biol 1988;106:761-71.

36. Denhardt DT, Edwards DR, McLeod M, Norton G, Parfett CLJ, Zimmer M. Spontaneous immortalisation of mouse embryo cells: strain differences and changes in gene expression with particular reference to retroviral gag-pol genes. Exp Cell Res 1991;192:128-36.

37. Draize JH, Kelly EA. Toxicity to eye mucosa of certain cosmetic preparations containing surface active antigens. Proc Sci Sect Toilet Goods Assoc 1952;17:1-4.

38. Parnigotto PP, Bassani V, Montesi F, Conconi MT. Bovine corneal stroma and epithelium reconstructed in vitro: characterisation and response to surfactants. Eye 1998;12:304-10.

39. Griffiths M, Osborne R, Munger R, Xiong X, Doillon CJ, Laycock NLC, et al. Song Y, Watsky MA. Functional human corneal equivalents constructed from cell lines. Science 1999;286:2169-72. 